\title{
Paracelsus (1493-1541): his relevance for modern health related policy
}

Citation for published version (APA):

Backhaus, J. G. (1995). Paracelsus (1493-1541): his relevance for modern health related policy. METEOR, Maastricht University School of Business and Economics. METEOR Research Memorandum No. 026 https://doi.org/10.26481/umamet.1995026

Document status and date:

Published: 01/01/1995

DOI:

10.26481/umamet.1995026

Document Version:

Publisher's PDF, also known as Version of record

\section{Please check the document version of this publication:}

- A submitted manuscript is the version of the article upon submission and before peer-review. There can be important differences between the submitted version and the official published version of record.

People interested in the research are advised to contact the author for the final version of the publication, or visit the DOI to the publisher's website.

- The final author version and the galley proof are versions of the publication after peer review.

- The final published version features the final layout of the paper including the volume, issue and page numbers.

Link to publication

\footnotetext{
General rights rights.

- You may freely distribute the URL identifying the publication in the public portal. please follow below link for the End User Agreement:

www.umlib.nl/taverne-license

Take down policy

If you believe that this document breaches copyright please contact us at:

repository@maastrichtuniversity.nl

providing details and we will investigate your claim.
}

Copyright and moral rights for the publications made accessible in the public portal are retained by the authors and/or other copyright owners and it is a condition of accessing publications that users recognise and abide by the legal requirements associated with these

- Users may download and print one copy of any publication from the public portal for the purpose of private study or research.

- You may not further distribute the material or use it for any profit-making activity or commercial gain

If the publication is distributed under the terms of Article $25 \mathrm{fa}$ of the Dutch Copyright Act, indicated by the "Taverne" license above, 
revised, 21-09-1994

PARACELSUS (1493-1541): HIS RELEVANCE FOR MODERN HEALTH RELATED POLICY

Prof. Jürgen G. Backhaus

Rijksuniversiteit Limburg

P.O. Box 616

6200 MD MAASTRICHT

The Netherlands 


\begin{abstract}
Half a millenium ago, Theophrast Bombast von Hohenheim who called himself Paracelsus (1493-1541) entered this world in order to revolutionize thought on health care related issues in ways that seem strikingly modern today. Although to a large extent Paracelsus was still a man of the middle ages, he was pushing for approaches not only to reform medical practice itself but also the entire system of health care delivery. His approach emphasized the social conditions surrounding illness, healing and health. In this vein, he was for instance the founder of the subdiscipline of the study of occupational diseases, but he is also generally considered as being the one wandering scholar who laid the foundation on which modern pharmaceutical methods rest. This essay first gives a short sketch of Paracelsus' life, then offers a few samples of his insights taken from his arcane original German, and proceeds by offering an overview over the remainder of this volume of the International Review of Comparative Public Policy, which contains eleven articles on unorthodox aspects of health related issues in an international comparative public policy perspective.
\end{abstract}

JEL codes: B15, I1 
PARACELSUS (1493-1541):

\section{HIS RELEVANCE FOR MODERN HEALTH RELATED POLICY}

Prof. Dr. Jürgen G. Backhaus

One of the biggest issues in International Comparative Public Policy is the reform of health care delivery. In 1993, the US administration of President Clinton started to launch attempts at introducing a national health care system for the United States. In 1994, the biggest UN conference ever held in Cairo discussed health care related issues with respect to human reproductive behaviour. There is hardly no Central European country that is not currently busy with some major health care overhaul: Britain, 
The Netherlands, Germany, France etc. are all engaged in health care reform. While on the one hand the advent of specific diseases such as AIDS, a wide spread occurrance of conditions such as drug addiction, stress or obesity as well as our better understanding of occupational diseases enhance the demand for health care delivery, the availability of new techniques, the increasing success of these techniques and treatments with the result of a prolongation of people's lives as well as structural defects in the organisation of health care delivery systems make these needs ever more difficult to be satisfied. Increasing demand meets exploding costs, and politicians arrive at the scene to look for and to provide new solutions to these intractable problems.

Sometimes, new solutions can be found in old scripture. Half a millenium ago, Theophrast Bombast von Hohenheim who called himself Paracelsus (1493-1541) entered this world in order to revolutionize thought on health care related issues in ways that seem strikingly modern today. Although to a large extent Paracelsus was still a man of the middle ages, he was pushing for approaches not only to reform medical practice itself but also the entire system of health care delivery. His approach emphasized the social conditions surrounding illness, healing and health. In this vein, he was for instance the founder of the subdiscipline of the study of occupational diseases, but he is also generally considered as being the one wandering scholar who laid the foundation on which modern pharmaceutical methods rest. This essay first gives a short sketch of Paracelsus' life, then offers a few samples of his insights taken from his arcane original German, and proceeds by offering an overview over the remainder of this volume of the International Review of Comparative Public Policy, which contains 17 articles on unorthodox aspects of health related issues in an international comparative public policy perspective.

I. His Life.

Theophrast Bombast von (ab) Hohenheim was probably born on the 11th of November of 1493 in Einsiedeln in the Swiss canton of Schwyz. He died in Salzburg (Austria) on September 24, 1541. The son of a Suabian noble man who spent his life as a wandering physician, and a Swiss serf belonging to the monastery of Einsiedeln, Hohenheim who called himself Philippus Aureolus Theophrastus Paracelsus spent his life, like his father, as a wandering physician, but also as a natural scientist and 
philosopher. In 1524 and 25 he practiced in Salzburg, in 1526 and 27 in Strassbourg, in 1527 and 28 he became the city physician and professor of medicine in Basel, but not at the university. Being forced out of Basel, he wandered about southern Germany and practiced in numerous southern German cities. In his many publications he attacked orthodox medicine and strove for a fundamental reform of medical teaching and practice. He essentially covered all aspects of medicine as it was then known, but he went beyond medicine and tried to place the human condition within the broader social context. He gained respect by his sometimes stunning successes in treatment, due to introducing elementary chemistry into medical practice. For instance, he cured Erasmus of Rotterdam. He used his prestige as a non-orthodox physician to also preach ethics, social policy and social philosophy, not always with great success. His social scientific writings were only published recently, almost five hundred years after his birth, and his contemporary publications cannot always be considered authentic, as students and competitors used his work which, at the time, was not yet protected by authors' rights.

So strong were his views on ethical questions including billing practices - he insisted on wealth based billing, treating the poor for free but insisting on super normal fees from the rich - that he was thrown out of a first story window by the servants of a wealthy patient whom he had cured, having asked to be paid. This caused his death on September 24, 1541.

The colorful personality of Paracelsus has inspired many people after him: Health care reformers, poets, novelists and increasingly in particular during the last three decades scholars in medicine and the social sciences as well as, occasionally, professionals who spend their day in health policy related fields. This volume of the International Review of Comparative Public Policy is devoted particularly to essays which deal with the last two categories. The essays take inspiration from Paracelsus, but do so in different ways, and all of these essays try to help us better understand health care related issues as we face them today.

II. His approach

In order to give an idea of the approach and specific style of Paracelsus, I have selected quotes from 
his work, which I shall reproduce and translate in this section. The quotes point to the vicissitudes of the life and the practice of this wandering scholar. The first quote emphasizes his empirical research method, but it also emphasizes the determination with which Paracelsus pursued his research. Other quotes emphasize the shaky material basis of his existence, although he did indeed die a rich man: whereas the last quote not only allows conclusions about relationships with his patients, but also about the form competition took between different physicians.

\section{"Everywhere, I have studied the art of medicine."}

All the time, and with great and unrelenting efforts I have tried to understand the basic reason of medicine, in order to understand whether medicine can really be called an art, or not, and what basically it consists in. I have been driven in this by various causes. Among them are the uncertainty with which our treatments are wrought which is reflected in the low esteem and the lack of applause of our daily practice: likewise, that so many patients perish: that they die, remain paralysed or are abandoned by their doctors. And this is not only the case with respect to just particular conditions, it is true for pretty much all the conditions. Our entire practice is uncertain."

In the following paragraphs, ${ }^{2}$ Paracelsus continues by contrasting his own fervent desire to comparatively study with the dogmatic approach of his colleagues who base their diagnosis and treatments on classical scriptures instead of empirical observation. Paracelsus, who received his doctorate in both medicines (i.e. internal and external) in 1515 or 1516 at the University of Ferrara, then continues to describe his extensive studies at universities (he studied in Tübingen, Heidelberg, Leipzig, Vienna and Ferrara) but also his extensive practical experiences in Granada, Portugal, Slovenia etc. in order as he himself puts it, to enquire and study in all these different countries and places, diseases and forms of treatment. Importantly his references were "not only learned doctors, but also practical medics, barbers, medical practitioners, women, magics, alchemists, the monks and nons in the monasteries," in short any type of evidence that he could find from the various people associated with medical practice. 
Paracelsus emphasizes the frustration ${ }^{3}$ he repeatedly suffered in trying to arrive at the one comprehensive understanding of medicine. Whereas he felt medical discourse often to be besides the point and empty, he wished his medical art to be "true and honest, just and certain, complete and total, a reliable art in times of need and an art equally useful to all patients in order to serve their health". In critisizing his contemporary medical authors for essentially producing useless book knowledge, Paracelsus insists that the only form of acquiring medical knowledge is the extensive migration through the different countries, as only the varying conditions of climate and geography with the appropriately differing treatments allow for sufficient comparison between medical practices and treatments. He held the belief that each condition, as it was caused by the specific features of time and place, also had an appropriate treatment that could be found in the same environment in which the condition prevailed. In the same vein, he emphasized $^{4}$ the importance of learning from military medical practice, pointing to his own participation in wars in the Netherlands, Romania, Napels, Venetia, Danmark etc. and his ability to successfully treat patients under these conditions of adversity. Finally ${ }^{5}$, as it is obvious that his relationship with his peers was less than harmonious, he emphasizes his standing with his patients "But I thank God: the sick liked me well."

Repeatedly ${ }^{6}$, Paracelsus emphasizes the harsh life of the travelling doctor, not only in a material sense, but also in terms of sacrificing the good and stable life.

The final two quotes deal with medical remuneration and honest forms of medical practice. As Paracelsus had defined the art of medicine also to have to be a just one, a just fee for medical services rendered he deams to be absolutely necessary ${ }^{7}$. But patients, whereas they are more than willing to pay for any kind of amusement, are reluctant to pay for medical services. If the treatment was not successful, a fee is deamed to be unnecessary too. And if it has been successful, says Paracelsus, the patient hides when it comes to paying the fee. In the last quote ${ }^{8}$, he describes a particular incident, where a rich patient sends for his services with the promise of a generous fee. The patient with a chronically sick leg, who has already suffered different treatments in vein, sends for Paracelsus who first refuses to come, due to the long distance of travel required. He finally makes the trip, and is welcomed in the patient's house. He applies a particular chyro-practical treatment, and first heals the patient's arm. The patient's 
family doctor learns the treatment by looking on and continues the practice, even breaking into Paracelsus' room and taking away some medicine. The upshot is that the doctor receives no payment that reflects his extensive medical expertise which he had gathered during his long journeys.

III. His Influence

The essays in this volume have been grouped into four major parts. The first part containing just one essay, is based on a close reading of the voluminious work left by Paracelsus. Note the extraordinarily rich list of references. This essay covers Paracelsus' recently discovered and edited social writings. This point is clearly one of Paracelsus' strongest achievements even in the eyes of the most orthodox medical practitioners. The way he approaches e.g. his treatment of occupational diseases also provides the foundation of what is today called the social scientific approach to health care delivery. The advent of schools of health sciences next to schools of medicine underscores this insight, which originally we owe to Paracelsus.

The second part of this volume is devoted to an impact analysis of Paracelsus' work, in this case on the basis of the literature published in English and accessible through modern library computer assisted research methods. The authors divide their subject matter into two essays. Essay one pursues the question of how one can address the issue of the impact of a social scientist, who was born five hundred years ago, on the social sciences before there were any social sciences. As was mentioned above, it did indeed take almost five hundred years to realize how important Paracelsus was as a social scientist. Yet, as Mary and Peter Senn demonstrate, his influence also helped create our modern social sciences. This is the topic of the second essay, which actually gives the impact study, the conditions of which are discussed in the first essay.

The third part of this volume is devoted to issues of social and health policy. As was pointed out before, the treatment of conditions according to Paracelsus has to take into account the entire social context in which the patient suffers and experiences illness, healing and health. It is to these conditions that 
social policy is addressed. The first essay by Wolfgang Drechsler discusses the role of Benjamin Distraeli in the construction of the British welfare state, and he reveals, by staying true to original statements, surprising insights into the current condition of the British welfare state. Mark Blum, on the other hand, emphasizes the humanities tradition as started by Paracelsus, but continued by Goethe and Jung. This is a very elaborate interpretive essay using a method developed in earlier studies and showing how there is a direct line of descendancy from Paracelsus through Goethe to Jung. The third paper in this section discusses the treacherous issue of eugenics, certainly a Paracelsian issue, with modern economic and ethical approaches.

The fourth and final section is devoted to health policy techniques, also an aspect emphasized by Paracelsus. The first paper in this section traces the history of quantitative methods to be used in health related areas from about Paracelsus' time to today. On these methods we can build the contemporary techniques of evaluating different treatments with respect to benefits and costs, which is the topic explored in the 15th and 16th essay. The 17th essay, finally, in building on these quantitative methods shows how very much in the spirit of Paracelsus, this very difficult set of data can be handled through workable public choice based processes which enable citizens who can be either tax payers or patients to make responsible decisions.

The essays collected in this volume were originally prepared for and discussed during the Fifth Annual Heilbronn Symposion in Economics and the Social Sciences, which took place in 1993 and was devoted to the contemporary relevance of the Paracelsus heritage. The essays have been refereed and revised according to the referee' reports received and the results of the discussions in Heilbronn. I should like to thank the authors for their work, the necessarily anonymous readers for their critique, but in particular the city of Heilbronn for its continued support of the annual symposion. Special thanks go to the Lord Mayor, Dr. Manfred Weinmann, and the director of the city archives, Dr. Christhard Schrenk. 


\section{The original German reads: Allerwärts die Arzneikunst erforscht}

Ich hab je und je mit großem Aufsehen fleißiger Arbiet mich geflissen zu erfahren den Grund in der Arznei, ob sie doch möge eine Kunst geheißen werden, oder sein, oder nicht, oder was doch in ihr seie. Denn dazu hat mich bewegt vielerlei Ursach, nämlich das Ungewisse des Fürnehmens in dem, daß so wenig Lob und Ehr mit sampt den Werken erschienen sind, daß soviel Kranken verdorben, getöt, erlähmt und gar verlassen worden sind. Nit allein in einer Krankheit, sondern gar nahet in allen Krankheiten. Also ungewiß war. Daß doch bei meinem Zeiten kein Artz gewesen ist, der doch nur gewiß möchte ein Zahnweh heilen, oder noch ein minders, geschweig große Krankheit.

Auch bei allen Alten solche Torheit gefunden in ihren Gschriften und darbei gesehen bei den Fürstenhöfen, bei den großen Städten, bei den Reichen, daß sie so groß Gut erbieten zu geben und doch bei allen Arzten verlassen waren in der Hilf, die doch in Seiden, gulden Ringen usw. gingen, nit mit kleinem Namen, Pracht und Geschwätz.

Hab ich auf solichs mehrmalen für mich genommen diese Kunst zu verlassen. Denn im Grunde zu bedenken, dieweil niemand un keinem andern gewiß sei, es sei ein Fabelwerk und ein süß Mißlocken des Pfennings. Hab oft von ihr gelassen und mit Unweillen in ihr gehandelt.

2 The original German reads: Doch aber mir selbs hierin ganze Folg nit geben, sondern meiner Einfalt zugemssen. Hab also die Hohen Schulen erfahren lange Jahr bei den Teutschen, bei den Italischen, bei den Frankreichischen und den Grund der Arznei gesucht. Mich nit allein derselbigen Lehrer und Gschriften, Büchern ergeben wöllen, sonder weiter gewandert gen Granaten (Granada), gen Lizabone durch Hispanien, durch Engeland, durch den Mark, durch Prüchsen (Preußen), durch Litau, durch Poland, Ungern, Walachi, Sibenbürgen, Crabaten (Kroatien), Windisch mark, auch sonst andere Länder, nit not zu erzählen. Und in allen den Enden und Orten fleißig und emsig nachgefragt, Erforschung gehabt, gewisser und erfahrner wahrhaften Künsten der Azrnei. Nicht allein bei den Doctoren, sondern auch bei den Scherern, Badern, gelehrten, Arzten, Weibern, Schwarzkünstlern, so sich des Pflegen, bei den Alchimisten, bei den Klöstern, bei Edlen und Unedlen, bei den Gescheiten und Einfältigen.

Hab aber so ganz gründlich nicht mögen erfahren, gewiß zu sein, es sei in was Krankheit es wöll. Hab ihm viel nachgedacht, daß die Arznei ein ungewisse Kunst sei, die nicht gebührlich sei zu gebrauchen, nicht billig mit Glück zu treffen, einen gesund macht, zehn dagegen verderbt. Das mir ein Ursach geben hat, es sei ein Betrügnis von Geistern, den Menschen also zu verführen und gering zu machen.

3 The original German reads: Hab abermals von ihr gelassen, in ander Händel gefallen, jedoch aber wiederumb in diese Kunst gedrungen. Doch gefunden den Spruch Christi: die Gesunden bedürfen kein Arztes, allein die Kranken. Bewegt mich soviel, daß ich mir mußt ein ander Fürnehmen fürsetzen, nämlich daß die Kunst wahrhaftig, gerecht, gewiß, vollkommen und ganz wär, in Nöten eine bewährte nothafte Kunst,allen Kranken nützlich und behilflich zu ihrer Gesundheit. Da ich mir solchs fürnahm und für mich fasset, war von nöten zu bedenken, was doch die Arznei wär, die ich aus den Büchern und andern gehört hätt. Befand soviel, daß von ihnen keiner diese Kunst in Grund nie gewißt, noch erfahren, noch verstanden hat. Und daß sie um die Kunst der Arznei gangen sind und noch gingen, wie ein Katz um den Brei. Und daß sie lehrten, was sie selbs nicht wußten, daß sie ihr disputieren nicht verstunden, und daß sie die Kranken heimsuchten und ratschlagten. Erkannten weder Krankheit noch Kunst darzu, und daß also der Fehl allein war in dem, der sie brauchte. Daß so viel geredt ward und ist; Schreier und Schwätzer waren sie in Pracht und Pomp und war in ihnen nichts, als ein totes Grab, das auswendig schön ist, inwendig ein stinkend fauls Aas voller Würm. Auf solches ward ich gezwungen fürbaß zu suchen und eim anderen Grund nachzufahren, der do unbefleckt sei mit den besagten Fabeln und Klappern. (10:19) 
4 The original German reads: Die Erfahrung in aller Welt studiert

Auf solchs ist not, daß ein jetlicher sei ein Cosmographus, ein Geographus und hab seine Folia mit den Füßen treten, mit den Augen gesehen, was einem jetlichen Land anliegt und was die Theorica nationum in ihr selbst demonstrative den Arzten fürhält. Darumb ist not Erfahrung der Terrarum, wie viel seinerlei Species seind begriffen in seinen Regionibus.

Darum, will ein Artz ein Theoreticus sein, so muß er perambulanisch handeln,peregrinisch und mit Landstreichung die Blätter in Büchern umkehren, nicht der Mutter im Schoß braten Feigen an eim Spießlein essen. Wie dann bisher die Scribenten nichts weiter erfahren haben als so weit, daß sie den Ofen alle mal bald wieder erlangen mögen. Das ist in der Stuben ist ihr Erfahrnus und in der Stuben wird allein erfahren, was die Fantasei gibt, also ohn den rechten approbierten und wahrhaften Grund.

Wöllt ihr euch des beschämen zu wandern, zu suchen ein Ding da, wo es ist, so möget ihr nicht an das End kommen. Was schadt das, daß du lernest was dich deine Augen lernent, was dich die Experienz lernet? Müssen nicht solche Ding also gelernet werden durch die Augen? Und die Augen, die dann in der Erfahrenheit ihre Lust haben, dieselbigen seind deine Professoren. Denn dein eigen fantasieren und dein eigen speculieren mag dich dahin nicht bringen, daß du dich möchtest ein Arzt zu sein berühmen. (11:27)

Ich soll nach euerm Urteil ein Chirurgus sein und kein Physikus. Womit wöllet ihr das beurteiln, dieweil ich doch offenbarlich 18 Fürsten - durch euch verlassen - in Physica aufgebracht hab; ohne Ruhm zu schreiben. Dieweil ich auch im Niderland, in der Romanei, in Neapolis, in Venedischen, Denemerkischen und Niderlendischen Kriegen so treffentliche Summa der Fiebrigen aufbracht und ob den 40erlei Leibkrankheiten, so in denselben funden worden, in Gesundheit aufgericht. Soll auf solches kein Leibarzet sein, der euch die Lügen der Scribenten umkehrt, der euch die Irrsal und Mißbräuch anzeigt, deren End begehrt zu sehen, den ihr fliehet. Meine Erfahrenheit, die ich aus Littau, Holland, Ungern, Dalmatien, Kroatien, Rodis, Italien, Frankreich, Hispanien, Portugal, Engelland, Denmark und allen deutschen Landen mit großem Fleiß überkommen hab, soll ein Hohn und Spott sein? Darum ich vermeint ein Lob davon zu haben und euch gedient, aber ihr streut Hochfahrt wider mich aus. Ist auch nicht Löblich die Gunst wider mich zu brauchen. (7:374)

\section{The original German reads: Den Kranken gefiel ich wohl}

In diesem meinem Schreiben will ich, daß mir kein getreuer Arzt nicht für arg aufnehm mein hitzig Schreiben, verhoff auch vor ihnen gut Ruh zu haben und gut Lob. Der andern Zottler achte ich nicht, ihr schelten ist mein Lob, mein Nutz und meins Seckels Fug. Denn ich weiß der Bescheißer so viel, daß unter 1000 Arzten nicht einer sprechen wird: Theophraste, hab dank, aber er ist ein Narr!

Unser Krieg ist lang gangen gegen einander. Sie trieben mich aus Littau, darnach aus Preußen, darnach aus Poland, war nicht genug. Ich gefiel den Niderlendern auch nicht, den Universitäten nicht, weder Jüden noch Mönchen. Ich dank aber Gott: den Kranken gefiel ich. (6:180)

\section{The original German reads: Die Not des landfahrenden Arztes}

So wir unser Elend und Verlassenheit sollen betrachten und müssen, lieben Filii, wie wir so viel beschwerter Herberg und Hunger mit viel seinen schmählichen Zuständen, die uns so gar umgeben hatten, daß wir nit zu grünen noch zu ufrichten kommen mochten, also lang wir der Arznei, wie die Alten sie beschrieben hatten, Nachfolger waren. Sondern mit viel Armut und Jammer gefangen und bittern Ketten gebunden und das alles zu ungutem erschuß. (3:93)

7 The original German reads: Um das Arzthonorar betrogen

Der Kranken Art ist, daß sie den Arzt empfindlich bescheißen. So nun einer genest, so begehrn sie im 
nüt drumb zu gehen. Dann nit allein die Kranken, sondern auch am Gericht, dort urteilt man darüber, als wär es "schuhmachen", da einer muß sein Leib und Leben wagen. Mißrät es, so will man gar nichts tun; geräts wohl, so verbergen sie sich, daß sie den Arzt nimmer sehen; ist böser, als der Teufel. Schenkt ers, ists gut, wo nit, so gehts ans schelten und verachten. Kein Geld wird baß verdient und übler gegeben als dieser Lidlohn(Honorar). Spielen, huren, saufen, das ist alles gutwillige Zahlung. Aber Leibesnot abzuwenden, ist aller Kranken Meinung, gar nit drum zu geben. (6:180)

\section{The original German reads: Betrügerische Kranke}

Mein Elend, das zu Eßlingen anfing, bestätigten die Nürnberger. Nun in allem dem, wie ich allda betrogen ward, stellt mir der Steffen nach. Also ging es.

In der oberen Pfalz liegt ein Städtlin, heißt Amberg. Darin ist ein Bürger, heißt Bastian Castner. Derselbig nach langer erlittner Krankheit in einm Bein, durch viel Händ der Arzte geloffen, hin und her: alle Ding versucht, jedoch je länger, je böser, nichts ersprießliches, soviel daß weder Ruh noch Rast da war. Dieser, dieweil ich in Regensburg war, ließ er durch den Bernhard, Münzmeister daselbst, an mich reichen, daß ich ihn besichtige. Das beschieht. Sein Reichtum wird mir angezeigt, auch eine große Verheißung, wie dann in Nöten alle Kranken gebrauchen, aber je näher dem End, je weniger zu halten bedächtigt sind.

Dieses geschieht. Nun hätte gebührt, daß er mir hätt den Ritt von 8 Meilen bezahlt; aber das war zu viel guts, wie dann der Reichen gemeiner Brauch ist. Und schied also wieder von ihm ab, meines Vorhabens, nichts mit einem solchen Mann zu handeln, der nit der Ehren wär und das Geld geben für den Ritt wie sich gebührt. Denn wo im Anfang ein solcher Filz ist, was soll sich der Arzt am End dazu versehen? Ich werde überredt vom Bernhard, der mit mir von des Ritts wegen abgeredet hat und vermacht einen Revers mit meim Geheiß, eine große Summ Gelds, so er gesund würde, zu geben an seiner statt.

Also nahm ich ihn an, und Essen und Trinken usw., kam im sein Haus, da geschah mir das. Darum ich allen Arzten rat, hütet euch vor Kranken, die Herberg und Speiß bei sich entbieten. Sie bescheißen euch all oder habens doch im Sinn. Nun hub ich an und heilte ihm zuerst den Arm.

Nun liegt die Kunst nit am heilen, sondern sie liegt an dem Griff damit nichts aufbreche am selbigen Ort oder an eim andern. Aber sein Bruder Doctor Burzli ist der Heilung nachgeeilt, und soweit er die Kunst begriffen hat, wie dann solch Apostüzler (Apolstelchen) die Künst erlangen, heimlich eingebrochen, Arznei auch gestohlen und ander Lügnere [gebraucht]. $(8: 258,259)$

Sie haben mir aus ihrem großen Neid die Gnad, die mir Gott gegeben zu entziehen unterstanden, damit ich genugsam in Verachtung käme und verworfen wurde vom Volk. Darin sie ihre Freud suchten und ihnen mehr und baß gefiel, so mir ein Kranker stürbe, denn gesund würde. In dieser Hinsicht haben sie keiner Lügen gespart, hin und her Zeugnis gesucht, das ihnen zum lügen hilflich. Und wie sie im Herzen waren, solche ihresgleichen gefunden, und zu Hilf genommen die Undankbarkeit und die erzwungene Bezahlung, so mir wider alles zusagen und verdienen gegeben ward [wie ich sie z. B. habe] empfangen müssen durch Markgraf Philipp von Baden, den ich nach allem Verderben durch seine Leibärzte aus der Dysenteria erlöst hab im letzten seines Lebens. Während mir zugesagt fürstliche Belohnung, unfürstlich begegnet, mit mehr Schaden, als da ich dem Juden, der alle Welt beschissen hat, Messe von Talles, in seiner Not half. Arger ward ich vom Fürsten bezahlt! Welches Fürsten Undankbarkeit und unfürstliche Belohnung meinen Feinden eine Freud war und ein Stichblatt wider mich, auch von anderen Herren und dergleichen, so mir auch solches bewiesen haben. (8:34) 


\section{REFERENCE}

Paracelsus: Leben und Lebensweisheit in Selbstzeugnissen, Leipzig: Verlag Philipp Reclam Jun. 1944 (selected and with an introduction by Karl Bittel) 